\title{
SS-DISCRETE MODULES
}

BURCU TURKMEN ${ }^{1}$ and Figen Eryilmaz ${ }^{2}$

${ }^{1}$ Amasya University

${ }^{2}$ Ondokuz Mayis University

September 18, 2020

\begin{abstract}
In this paper, we define semi-ss-discrete and quasi-ss-discrete modules as a strongly notion of semi-discrete and quasi-discrete modules with the help of ss-supplement in [3]. We examined the basic properties of these modules and included characterization of strongly ss-discrete modules over semi-perfect rings.
\end{abstract}

\section{Hosted file}

ss-discrete modules.pdf available at https://authorea.com/users/360031/articles/481765-ssdiscrete-modules 